\title{
Analisis yuridis pengaturan pengelolaan zakat dan pajak menurut sistem hukum di Indonesia dan Malaysia
}

\author{
Yudi Wicaksono Pratama ${ }^{1}$, Kadek Wiwik Indrayanti ${ }^{2}$
}

${ }^{1}$ Yudi Wicaksono Pratama; Program Magister Ilmu Hukum Universitas Merdeka Malang; Jl. Terusan Raya Dieng Nomor 62-64; Malang; 65146; Jawa Timur; Indonesia.

${ }^{2}$ Kadek Wiwik Indrayanti; Fakultas Hukum Universitas Merdeka Malang; Jl. Terusan Raya Dieng Nomor 62-64; Malang; 65146; Jawa Timur; Indonesia.

\section{A R T I C LEINFO}

Article history:

Received 2020-12-19

Received in revised form

2021-02-17

Accepted 2021-04-01

Kata kunci:

Pengelolaan Zakat; Pajak;

Indonesia; Malaysia.

Keywords:

Zakat Management; Tax; Indonesia; Malaysia.

DOI: https://doi.org/10.26905/

idjch.v12i1.5724.

How to cite item:

Pratama, Y. W., Indrayanti, K. W. (2020). Analisis yuridis pengaturan pengelolaan zakat dan pajak menurut sistem hukum di Indonesia dan Malaysia. Jurnal Cakrawala Hukum, 12(1). 110-119. doi:10.26905/ idjch.v12i1.5724.80.

Corresponding Author:

* Yudi Wicaksono Pratama.

E-mail address: Yudi.Wicaksono@gmail.com.

\section{Abstrak}

Paper ini bertujuan untuk mengkaji perbandingan model pengaturan pengelolaan zakat dan pajak menurut sistem hukum di Indonesia dan Malaysia. Metode penelitian yang digunakan adalah penelitian hukum normative dengan menggunakan pendekatan perbandingan (comparative approach) dan undangundang (statute approoach). Hasilnya menunjukkan bahwa pemerintah Indonesia dan Malaysia memiliki peran sebagai fasilitator dalam pengelolaan zakat \& pajak. Pajak dikumpulkan secara terpusat, dan diatur oleh Undang-Undang. Sedangkan Perbedaan pengelolaan zakat dan pajak di Indonesia dan Malaysia yaitu terletak pada lembaga pengelola zakat, pengaturan zakat dalam undang-undang, Badan pengawas lembaga pengelola zakat, badan pengelola dan penyalur dana zakat, Program pengelolaan dana zakat. Adanya permasalahan pengelolaan zakat di Indonesia yaitu pengelolaan zakat masih dilakukan secara sederhana, rendahnya tingkat kepercayaan masyarakat kepada lembaga amil zakat, adanya dualisme institusi pengelola zakat, lemahnya penerapan prinsip pengelolaan organisasi, rendahnya penguasaan teknologi oleh institusi zakat dan rendahnya pemahaman zakat di kalangan masyarakat. Sehingga dapat direkomendasikan zakat penghasilan dapat disamakan dengan pajak penghasilan yaitu bukan sebagai faktor pengurang pajak penghasilan tetapi sebagai kredit pajak yang nonrefundable. perlu adanya regulator pengawasan dan koordinasi dan system koputerisasi.

\begin{abstract}
This paper aims to examine the comparison of the regulatory model for zakat and tax management according to the legal system in Indonesia and Malaysia. The research method used is normative legal research using a comparative approach and statute (statute approoach). The results show that the Indonesian and Malaysian
\end{abstract}


governments have a role as facilitators in managing zakat $\mathcal{E}$ tax. Taxes are collected centrally, and are regulated by law. Meanwhile, the difference between the management of zakat and tax in Indonesia and Malaysia is that it lies in the zakat management institution, zakat regulation in the law, the supervisory agency for zakat management institutions, the zakat fund management and distribution agency, and the zakat fund management program. There are problems in managing zakat in Indonesia, namely zakat management is still carried out in a simple manner, the low level of public trust in amil zakat institutions, the dualism of zakat management institutions, weak application of organizational management principles, low mastery of technology by zakat institutions and low understanding of zakat among the community. So it can be recommended that income zakat can be equated with income tax, namely not as a deduction factor for income tax but as a non-refundable tax credit. there is a need for a supervisory and coordinating regulator and a computerized system.

\section{Pendahuluan}

Badan Pusat Statistik pada bulan September Tahun 2019 mendata bahwa jumlah penduduk miskin nasional di Indonesia (penduduk dengan pengeluaran per kapita per bulan di bawah garis kemiskinan) mencapai 24,79 juta jiwa, atau setara dengan 9,45\% dari total penduduk Indonesia. Hal ini berarti membuktikan bahwa kesejahteraan di Indonesia masih menjadi persoalan yang serius. Disisi lain, mayoritas penduduk Indonesia adalah beragama islam, yaitu sekitar $85 \%$ dari total populasi. Fakta ini merupakan salah satu peluang yang seharusnya dapat dimanfaatkan secara optimal dalam menanggulangi kemiskinan dan memenuhi kesejahteraan di Indonesia, yaitu dengan mengoptimalkan pengelolaan zakat yang merupakan kewajiban dari setiap muslim.

Zakat sebagai satu dari rukun Islam yang memiliki ciri unik dibandingkan dengan rukun Islam yang lain, karena selain sebagai ibadah pribadi, zakat juga memiliki dampak sosial yang signifikan sebagai upaya distribusi kekayaan, yaitu mengurangi harta orang kaya dan menambah harta orang miskin untuk mengurangi kesenjangan sosial diantara keduanya (Inayah, 1995). Hal ini ternyata juga sesuai dengan laporan yang dipaparkan Badan Amil Zakat Nasional (BAZNAS), bahwa potensi zakat diperkirakan dapat mencapai 233,8 Triliun Rupiah pada tahun 2019. Sedangkan kontribusi saat ini yang disalurkan secara resmi melalui Organisasi Pengelola Zakat (OPZ) baru mencapai 3,47 \% dari potensi tersebut diatas (Baznas, 2018).

Selain zakat, ada lagi salah satu instrumen penting yang dikenal dalam sektor ekonomi nasional yaitu pajak. Pajak merupakan sumber pendapatan nasional terbesar, yaitu sekitar 70\% dari seluruh penerimaan negara. Pajak adalah kontribusi wajib seorang warga negara kepada negara yang terutang oleh orang pribadi atau badan yang bersifat memaksa berdasarkan undang-undang yang berlaku, serta dengan tidak mendapatkan imbalan secara langsung dan digunakan untuk keperluan negara bagi sebesar-besarnya kemakmuran rakyat di negara tersebut. Tetapi dalam implementasinya, pembayaran zakat sekaligus pembayaran pajak menjadi kontroversi di masyarakat karena dalam satu obyek yang sama terdapat dua kewajiban yang harus dibayarkan. Seorang muslim dengan penghasilan tertentu sudah pasti wajib membayar zakat, sedangkan sebagai warga negara wajib pula membayar pajak. Dengan demikian, sebagai warga negara Indonesia yang sekaligus sebagai seorang muslim dibebani kewajiban ganda, yakni membayar pajak untuk 
memenuhi kewajiban terhadap negara dan membayar zakat untuk memenuhi kewajiban terhadap agama. Padahal, baik pajak maupun zakat saat ini belum sepenuhnya terealisasi secara optimal di Indonesia.

Pengelolaan zakat di Indonesia diatur didalam Undang-Undang No. 23 Tahun 2011 tentang Pengelolaan Zakat. Undang-Undang yang lahir pada 27 Oktober 2011 ini menimbulkan kontroversi besar di dunia zakat nasional. UndangUndang No. 23 Tahun 2011 tentang Pengelolaan Zakat yang meregulisasi pengelolaan zakat modern di Indonesia yang sekuler dan demokratis, menimbulkan perdebatan sengit karena mengklaim berbasis pada "pendapat fikih klasik" bahwa hanya Negara yang memiliki otoritas dalam mengelola zakat. Undang-Undang ini menghapus sistem desentralisasi zakat nasional di bawah rezim Undang-Undang No. 38 Tahun 1999 tentang Pengelolaan Zakat dan menggantinya dengan sistem yang lebih terpusat. Hanya pemerintah yang mempunyai hak untuk dapat mengelola zakat nasional. Undang-Undang No. 23 Tahun 2011 tentang Pengelolaan Zakat melakukan penguatan dan memberi berbagai hak privilage kepada Badan Amil Zakat Nasional (BAZNAS) bentukan pemerintah dan melakukan marginalisasi dan pelemahan, bahkan berpotensi "mematikan" kepada Lembaga Amil Zakat (LAZ) bentukan masyarakat sipil (Wibisono, 2015).

Sedangkan di Wilayah Persekutuan Malaysia, pengelolaaan zakat dilakukan lembaga pusat yang bernama Pusat Pungutan Zakat (PPZ). Pusat Pungutan Zakat telah didirikan dan diresmikan pada tanggal 27 Desember 1990 berfungsi untuk melayani para pembayar zakat dengan menggunakan sistem komputerisasi. Penggunaan komputer pada saat itu untuk urusan memungut zakat adalah satu peristiwa yang sangat bersejarah karena belum pernah dilakukan baik di Malaysia atau di Negara lain. Lembaga tersebut merupakan perusahaan yang dikelola dengan baik oleh peme- rintah Malaysia. Pusat Pungutan Zakat (PPZ) dalam beroperasi hanya berwenang untuk menghimpunkan dana zakat masyarakat. Sedangkan, penyaluran dana zakat dilakukan oleh lembaga lain bernama Baitulmaal. Kedua lembaga tersebut diatas berada dibawah Majelis Agama Islam Wilayah Persekutuan (MAIWP).

Dalam laporan Pusat Pungutan Zakat (PPZ) Malaysia terungkap bahwa pendapatan zakat dan pajak memiliki korelasi positif (Aflah, 2009). Pengelolaan zakat yang berkaitan dengan pajak sudah dimulai sejak tahun 1990, yakni dengan menerapkan zakat pengurang pajak bagi sebuah perusahaan yang telah membayar zakat dengan diberikannya potongan pajak yang sangat kecil. Kemudian di tahun 2005 pemerintah Malaysia kemudian mengeluarkan suatu keputusan bahwa pembayaran zakat individu seorang warga negara yang telah dibayarkan dapat dijadikan pemotongan pajak penghasilan sampai $100 \%$, sedangkan zakat perusahaan dapat mengurangi pajak penghasilan 25\% saja. Menurut data pengumpulan zakat dan pajak yang ada di Malaysia disebutkan bahwa hingga tahun 2019, tingkat penerimaan zakat Malaysia sudah mencapai lebih dari 5 Miliar Ringgit Malaysia (RM) atau sekitar Rp17,4 triliun. Kemudian selama tiga tahun terahir setelah diberlakukannya zakat sebagai pengurang pajak di Malaysia, data penerimaan zakat dan pajak terus mengalami peningkatan yang signifikan.

Fungsi zakat seyogyannya dapat diwujudkan dan ditingkatkan sehingga zakat benar-benar bermanfaat bagi masyarakat. Untuk mendapatkan manfaat atau hasil maksimal dalam pemenuhan fungsi zakat sebagai aset pembangun kesejahteraan umat (Ali, 2010). Gambaran metode pengelolaan zakat dan pajak di Malaysia tersebut diatas masih perlu didalami dan dicermati kembali, jika dijadikan sebagai pedoman dan diterapkan di Indonesia.

Berdasarkan deskripsi diatas, maka akan mengkaji tentang persamaan dan perbedaan model 
pengaturan pengelolaan zakat dan pajakdi kedua negara, dan menganalisis upaya yang harus dilakukan dalam memperbaiki mekanisme pengelolaan zakat di Indonesia ditinjau dari Undang-Undang No. 23 Tahun 2011 tentang Pengelolaan Zakat.

\section{Metode}

Jenis penelitian yang digunakan penulis dalam penelitian ini adalah jenis penelitian yuridisnormatif. Pendekatan penelitian dalam penelitian ini adalah pendekatan perundang-undangan dan pendekatan konsep. Metode penelitian yuridisnormatif adalah suatu penelitian yang objeknya merupakan dokumen peraturan perundangundangan dan bahan pustaka (Abdurahman, 2003). Dalam penelitian ini peneliti menganalisis dan untuk Menganalisis secara yuridis pengaturan pengelolaan Zakat dan Pajak menurut sistem hukum di Indonesia dan di Malaysia. Pendekatan yang di gunakan adalah pendekatan PerundangUndangan. Selain perundang-undangan penulis juga menggunalan pendekatan perbandingan antara 2 (dua) Negara, yaitu Indonesia dan Malaysia. Pendekatan perbandingan dilakukan dengan mengadakan studi perbandingan hukum dengan hukum negara lain atau hukum dari suatu waktu tertentu dengan hukum dari waktu yang lain (Rizal, 2019).

\section{Pembahasan}

Berdasarkan hasil pengumpulan bahan hukum maka persamaan pengaturan pengelolaan Zakat dan Pajak di Indonesia dan Malaysia terdapat pada dua hal yakni peran negara dan pengaturan, yang keduanya sama-sama memberikan perlindungan hukum bagi warga negaranya. Istilah perlindungan hukum dalam bahasa inggris dikenal dengan legal protection, sedangkan dakam bahasa belanda dikenal dengan Rechts Bescherming. Dalam Kamus Besar Bahasa Indonesia perlindungan hukum diartikan (1). tempat berlindung,
(2). hal perbuatan, (3). proses, cara, perbuatan melindungi (Pramuditya, 2014).

Negara sama-sama memiliki peran yang sangat strategis dalam pengaturan pengelolaan zakat di Indonesia dan Malaysia. Indonesia dengan Pancasila sebagai dasar negara yang menempatkan agama sebagai salah satu landasan bernegara. Sila Pertama merupakan suatu landasan dari sila-sila yang lain. Sila pertama ini juga merupakan suatu dasar ontologis, epistimologis, dan aksiologis hubungan negara dan agama di Indonesia. Dengan demikian, agama mendapat legitimasi yuridis, filosofis, dan politis di Indonesia (Afriyandi, 2014). Dengan kata lain, hubungan antara agama dan negara di Indonesia adalah bersifat substansial yaitu terdapat ajaran dan nilai yang bersifat secara substantif yang mengandung prinsip etis dalam bermasyarakat, berbangsa dan bernegara.

Sedangkan di Malaysia yang juga dengan jumlah umat Islam sebagai umat mayoritas paling banyak di Malaysia, menempatkan agama Islam dengan lebih strategis, yakni dengan menempatkannya sebagai agama negara. Oleh karena itu, semua aturan yang berkaitan dengan agama Islam langsung berasal dari raja/sultan, sehingga ketaatan terhadapnya merupakan kewajiban terhadap agama sekaligus kewajiban terhadap negara. Pengelolaan pajak di Indonesia dilakukan dengan sistem selfassessment yang dikumpulkan secara terpusat kepada negara yang semua kewenangannya berada di bawah tanggung jawab Direktorat Jendral Pajak. Kemudian wilayah kerja dari Direktorat Jendral Pajak adalah meliputi tempat tinggal ataupun tempat domisili dari wajib pajak tersebut.

Pengaturan pengelolaan pajak di Malaysia juga sama-sama menggunakan sistem selfassessment. Pengumpulan pajak dilakukan secara terpusat kepada Lembaga Hasil Dalam Negeri (LDHN). LHDN merupakan badan utama di bawah Kementerian Keuangan di Malaysia yang mempunyai tanggung jawab untuk mengumpulkan dan mengelola pajak langsung negara-negara bagian 


\section{Jurnal Cakrawala Hukum, Volume 12 No. 1 April 2021}

ISSN PRINT 2356-4962 ISSN ONLINE 2598-6538

di Malaysia (Al-Mamun, dkk., 2015). Secara umum, semua semua wajib pajak harus membayar pajak atas semua jenis pendapatan termasuk pendapatan dari bisnis atau profesi, pekerjaan, dividen, bunga, diskon, sewa, royalti, premi, pensiun annuities dan lain sebagainya.

Perbedaan Pengaturan Pengelolaan Zakat dan Pajak di Indonesia dan Malaysia dapat dilihat dari dua aspek yakni: Pengaturan pengelolaan zakat sudah diatur dalam Undang-Undang No. 23 Tahun 2011 tentang Pengelolaan Zakat. Upaya pengelolaan zakat meliputi perencanaan, pelaksanaan, dan pengoordinasian dalam pengumpulan, pendistribusian dan pendayagunaan zakat, dibentuk dan dilaksanakan oleh lembaga Badan Amil Zakat Nasional (BAZNAS) yang berkedudukan di ibu kota negara, Badan Amil Zakat Nasional (BAZNAS) provinsi, dan Badan Amil Zakat Nasional (BAZNAS) kabupaten/kota.

Perbedaan dengan di Malaysia adalah pengaturan pengelolaan zakat dilakukan secara terpusat baik melalui pemerintah atau swasta. Menurut sistem perundang-undangan yang ada di Malaysia yaitu pada Pasal 3 ayat (4) menyatakan bahwa peraturan mengenai agama Islam di Malaysia berada di bawah kekuasaan Sultan atau Raja bagi negara bagian yang memiliki raja dan di bawah kekuasaan Yang Dipertuan Agung bagi negara bagian yang tidak memiliki Raja yaitu seperti di Wilayah Persekutuan Kuala Lumpur, Labuan dan Putrajaya. Oleh sebab itu, semua urusan administrasi dan pengelolaan segala jenis zakat di Malaysia berada di bawah kekuasaan pemerintah masingmasing negara bagian, sehingga undang-undang pengelolaan zakat juga pasti berbeda-beda disetiap masing-masing negara bagian di Malaysia (Suprayitno, 2013).

Dalam hal ini warga negara pemeluk agama Islam di Indonesia masih mendapatkan beban ganda, yaitu menunaikan zakat dan membayar pajak. Dengan diberlakukannya Undang-Undang No.23 tahun 2011 tentang Pengelolaan Zakat dan
Undang-Undang No.36 Tahun 2008 tentang Pajak Penghasilan memang secara eksplisit mengakui adanya perbedaan antara zakat dan pajak. Secara lebih khusus diatur didalam Pasal 22 UndangUndang No. 23 Tahun 2011 tentang Pengelolaan Zakat menyebutkan bahwa zakat yang dibayarkan oleh muzaki kepada lembaga Badan Amil Zakat Nasional (BAZNAS) atau kepada Lembaga Amil Zakat (LAZ) dapat dikurangkan atau dipotongkan pada pajak penghasilan tahunan. Hal ini dipertegas kembali dalam Pasal 4 ayat (3) huruf a angka 1 dan Pasal 9 ayat (1) huruf g Undang-Undang No. 36 Tahun 2008 tentang Pajak Penghasilan. Selanjutnya, peraturan tentang zakat sebagai pengurang pajak penghasilan juga telah diatur didalam Peraturan Pemerintah No.60 Tahun 2010 tentang Zakat atau Sumbangan Keagamaan yang Sifatnya Wajib yang dapat dikurangkan dari Penghasilan Bruto.

Perbedaannya dengan di Malaysia adalah zakat dapat menjadi pengurang pajak penghasilan bagi pembayar zakat yang telah membayarkan zakatnya melalui Pusat Pungutan Zakat (PPZ). Melalui sistem potongan pajak secara berjadwal atau sistem potongan bulanan (PCB), para pembayar zakat tersebut akan menikmati pengurangan pajak penghasilan sebesar jumlah pembayaran zakatnya, atau dengan kata lain zakat dapat digunakan untuk mengurangi pajak sampai $100 \%$ (Percukaian Akta 53, 2. 6A (3)). Kemudian sejak tahun 2005, pemerintah Malaysia telah mengeluarkan kebijakan menerima zakat perusahaan menjadi pengurang pajak sebesar $25 \%$. Tujuannya sebagai salah satu cara untuk menghindari adanya pembayaran atau pembebanan pajak berganda kepada hasil pendapatan para pembayar zakat dan pajak di Malaysia.

Upaya yang harus dilakukan dalam memperbaiki pengaturan pengelolaan zakat di Indonesia ditinjau dari Undang-Undang No. 23 Tahun 2011 tentang Pengelolaan Zakat, jika lebih diteliti kembali potensi penerimaan zakat yang ada di 
Indonesia sesungguhnya sangatlah besar, karena melihat masyarakat di Indonesia yang mayoritas memeluk agama islam. Hal tersebut juga dapat terlihat dari data-data yang telah disampaikan oleh Badan Amil Zakat Nasional (BAZNAS) bahwa potensi zakat di Indonesia mencapai 233,8 Triliun pada 2019. Sedangkan kontribusi saat ini yang disalurkan secara resmi melalui Badan Amil Zakat Nasional (BAZNAS) dan Lembaga Amil Zakat (LAZ) baru mencapai 3,47\% dari potensi tersebut.

Tujuan awal zakat tersebut adalah untuk dapat mewujudkan keadilan dan kemakmuran yang merata di dalam kehidupan masyarakat. Permasalahan zakat adalah sesuatu yang tidak pernah habis dibicarakan, wacana tersebut terus bergulir mengikuti perkembangan peradaban Islam. Walaupun dorongan untuk merealisasikan zakat saat ini cukup besar, namun masih terdapat masalahmasalah tertentu yang menjadi hambatan pelaksanaannya.

Dalam hal ini konsepsi fikih zakat yang dimaksudkan yaitu perihal zakat hasil ijtihad para ulama yang dipahami oleh masyarakat. Karena di dalam Al-Quran seperti kita ketahui hanya tercantum pokok-pokok perihal zakat saja, yang akhirnya kemudian dijelaskan lebih lanjut oleh Sunnah Nabi Muhammad SAW. Kemudian penjabaran yang tercantum dalam kitab-kitab fikih lama, tidak sesuai lagi dengan keadaan zaman sekarang.

Dalam hal ini pembenturan kepentingan yang dimaksudkan yaitu terbenturnya kepentingan dari organisasi dan lembaga pengelola zakat yang selama ini mengelola zakat, contohnya Badan Amil Zakat, Infaq dan Sodaqoh (BAZ atau BAZIS) merupakan suatu lembaga amil zakat yang sangat baru di kalangan masyarakat. Jika pengumpulan zakat yang dilakukan secara terkoordinasi oleh lembaga yang baru tersebut, maka akan menjadikan lembaga amil zakat yang sudah berdiri sejak lama akan merasa khawatir perihal kepentingan dan kewenangannya yang akan menjadi ter- ganggu.

Sebagai contoh terdapat pula hambatan politis dalam penyelenggaraan pengumpulan zakat ini, sebab di dalam masyarakat masih terdapat kelompok-kelompok yang menghubungkan ibadah zakat tentang Piagam penghargaan suatu Kota. Pandangan ini tentu saja tidak dapat dibenarkan, karena menurut Undang-Undang Dasar Republik Indonesia Tahun 1945 pasal 29 ayat 2 disebutkan bahwa negara menjamin kebebasan penduduk untuk beribadah menurut agamanya.

Seperti kita ketahui saat ini masyarakat Islam Indonesia memiliki tingkat kesadaran yang makin berkembang dalam hal menunaikan zakat. Akan tetapi di samping itu di dalam masyarakat Islam Indonesia juga terdapat sikap kurang percaya terhadap pengelolaan zakat tersebut. Hal tersebut sesungguhnya ditujukan kepada orang atau sekelompok orang yang mengelola zakat. Jika kita lihat sikap tersebut sebenarnya merupakan akibat dari pengelolaan suatu organisasi pada zaman dahulu, contohnya adalah sikap kurang percaya masyarakat perihal pengelolaan koperasi, akibat kesalahan yang dilakukan oleh para oknum pengurus koperasi tersebut.

Kemudian faktor penghambat yang terakhir yaitu para muzzaki (pembayar zakat) khususnya yang berada di daerah pedesaan, mereka memberikan zakat tidak kepada delapan golongan atau salah satu dari delapan golongan yang memang berhak untuk menerima zakat, tetapi kepada pemimpin agama setempat dimana mereka tinggal. Para pemimpin agama tersebut tidak menempatkan diri sebagai amil zakat yang mempunyai kewajiban menyalurkan zakat kepada delapan golongan atau salah satu dari delapan golongan yang berhak menerima zakat, akan tetapi malah menempatkan diri sebagai mustahiq (penerima zakat) yang jika dikatakan dalam kategori fisabilillah yaitu seorang muslim yang memperjuangkan jalan Allah SWT.

Selanjutnya terdapat kelemahan di dalam pelaksanaan Undang-Undang No.23 Tahun 2011 
Tentang Pengelolaan Zakat yaitu: Pertama, adalah mengenai izin pendirian lembaga amil zakat. Dalam pasal 57 Undang-Undang No.23 Tahun 2011 Tentang Pengelolaan Zakat, menyebutkan bahwa lembaga amil zakat dapat didirikan oleh organisasi masyarakat Islam ataupun lembaga yang mempunyai badan hukum. Namun klausa lembaga yang mempunyai badan hukum tersebut hilang pada pasal 58 Undang-Undang No.23 Tahun 2011 Tentang Pengelolaan Zakat. Hal tersebut mengakibatkan munculnya beda persepsi pada setiap orang yang menafsirkan pasal tersebut. Kemungkinan yang terjadi nantinya pendirian lembaga amil zakat hanya untuk organisasi masyarakat saja.

Kedua, perihal tentang pembentukan perwakilan Lembaga Amil Zakat Nasional (LAZNAS) yang hanya terdapat satu perwakilan di setiap wilayah provinsi, dan setiap perwakilan tersebut berkewajiban mengajukan izin kembali kepada kantor Kementerian Agama di suatu daerah yang akan didirikan Lembaga Amil Zakat Nasional (LAZNAS) sebagaimana disebutkan di pasal 62 Undang-Undang No.23 Tahun 2011 Tentang Pengelolaan Zakat, khususnya di ayat 2 serta ayat 3. Hal tersebut menjadikan timbulnya pertanyaan, sebab kenyataan dilapangan yang ada memperlihatkan bahwa banyaknya Lembaga Amil Zakat (LAZ) yang telah membuka kantor perwakilan dengan jumlah lebih dari satu kantor perwakilan di satu provinsi.

Ketiga, berkaitan dengan kewenangan melakukan audit syariah yang dalam hal ini dilakukan oleh Kementerian Agama. Dalam hal ini memang sudah tepat dengan adanya audit. Namun yang jadi pertanyaan adalah wewenang lembaga yang melakukan audit, dalam hal ini bukan dari pihak Majelis Ulama Indonesia, akan tetapi malah melalui Kementerian Agama.

Kelemahan Pengelolaan Zakat dari Aspek Sosiologis adalah (1) terbatasnya pengetahuan masyarakat yang berkaitan dengan ibadah zakat. Pengetahuan masyarakat mayoritas tentang ibadah hanya seputar shalat, puasa, dan haji. 2) Konsepsi zakat, yang masih dirasa terlalu sederhana dan tradisional. Sehingga di dalam pelaksanaanya hanya cukup dibagikan langsung sendiri lingkungannya atau kepada kyai yang disenangi. 3) Kepercayaan muzzaki (pembayar zakat) kepada lembaga amil zakat masih rendah yang mana terdapat indikasi kekhawatiran dari para masyarakat muzzaki (pembayar zakat) bahwa zakat yang telah diserahkan kepada lembaga pengelola zakat, tidak sampai diterima oleh para mustahiq (penerima zakat) yang berhak menerimanya.

Selanjutnya Kelemahan pengelolaan zakat dari aspek institusi. Terdapat dualisme di dalam institusi pengelola zakat dalam menjalankan proses pengumpulan dan pendistribusian dana zakat. Sebagaimana tertuang di dalam Undang-Undang No. 23 Tahun 2011 Tentang Pengelolaan Zakat dan Keputusan Menteri Agama Nomor 373 Tahun 2003 Tentang Pengelolaan Zakat menyebutkan bahwa institusi pengelola zakat yaitu : Badan Amil Zakat adalah organisasi pengelola zakat yang dibentuk oleh pemerintah terdiri dari unsur masyarakat dan pemerintah dengan tugas mengumpulkan, mendistribusikan dan mendayagunakan zakat sesuai dengan ketentuan agama. Contohnya BAZNAS dan BAZDA. 2) . Lembaga Amil Zakat adalah institusi pengelola zakat yang dibentuk oleh masyarakat dan dikukuhkan oleh pemerintah untuk melakukan kegiatan pengumpulan, pendistribusian dan pendayagunaan Zakat sesuai dengan ketentuan agama. Sebagai contoh yaitu Dompet dhuafa, Pos Keadilan Peduli Ummat, YDSF, Rumah Zakat. Berdasarkan realita kedua lembaga tersebut sama-sama memiliki fungsi pengumpul dan penyalur dana zakat. Sehingga fungsi yang demikian di rasa kurang efektif dalam implementasinya di masyarakat.

Memecahkan berbagai masalah yang telah dikemukakan diatas, beberapa upaya perlu dilakukan diantaranya sebagai berikut: Penyebarluasan pengertian zakat dalam hal ini upaya dalam 
melakukan penyebarluasan pengertian zakat harus dilakukan secara baik serta benar. Lebih baik apabila upaya tersebut dilakukan lewat jalur pendidikan, baik itu pendidikan formal ataupun pendidikan nonformal. Penyebarluasan pengertian zakat secara masal tersebut dapat dilaksanakan melalui sosialisasi, khususnya perihal hukum zakat, harta yang wajib dikeluarkan zakatnya, pengorganisasian dan pendayagunaan zakat, yang tentunya harus disesuaikan dengan kemajuan zaman yang terus berkembang.

Membuat atau merumuskan fikih zakat yang baru dalam hal merumuskan fikih zakat yang baru diperlukan adanya kerjasama multidisipliner antar para pakar di berbagai bidang yang tentunya mempunyai hubungan erat dengan zakat, contohnya para pakar keilmuan Islam, pakar hukum fikih, dan lain-lain. Diharapkan dalam fikih zakat baru tersebut dapat menjadi wadah perkembangan pemahaman zakat yang sudah ada saat ini dan yang akan ada selanjutnya di Indonesia. Perihal harta yang wajib dikeluarkan zakatnya, lebih baik lagi apabila dapat dijelaskan lebih lanjut mengenai jenis barang yang mempunyai nilai ekonomis yang ada di masyarakat saat ini.

Pendayagunaan dana zakat yang tersedia di samping penyusunan fiqih zakat yang baru diatas, perlu juga disusun suatu pola umum pendayagunaan zakat di indonesia yang sesuai dengan kehidupan masyarakat ditanah air kita. Tentang pendayagunaan zakat perlu diingat bahwa zakat itu mempunyai dua fungsi utama. Pertama adalah membersihkan harta benda dan jiwa manusia supaya senantiasa berada dalam keadaan fitrah. Seseorang yang telah memberikan hartanya untuk disampaikan kepada yang berhak menerimanya berarti pula bahwa dia telah menyucikan harta dan jiwanya dengan pemberian itu. Kedua adalah zakat itu juga mempunyai fungsi untuk dana yang kemudian bisa digunakan oleh masyarakat sebagai keperluan sosial agar dapat mengurangi angka kemiskinan di Indonesia. Dalam hal yang kedua ini pemanfaatannya mempunyai arti yang penting, sebagai salah satu upaya untuk mencapai keadilan sosial bagi seluruh rakyat Indonesia.

Pengorganisasian zakat juga perlu dikelola sesempurna mungkin supaya proses distribusi zakat bisa diarahkan dan dikoordinasikan. Pengelolaan sangat dibutuhkan sebagai upaya dalam menguatkan tingkat kepercayaan yang ada di masyarakat serta para muzzaki (pembayar zakat). Selain keterlibatan para pemuka agama islam, dalam hal ini peran pemerintah sangatlah dibutuhkan. Dalam hal ini pola pengaturan pengelolaannya harus berdasarkan prinsip dari pengaturan sistem yang tertata supaya proses pengelolaan zakat bisa berjalan dengan sempurna.

Fundraising dapat diartikan sebagai kegiatan dalam rangka menghimpun dana dan sumber daya lainnya dari masyarakat (baik individu, kelompok, organisasi, perusahaan ataupun pemerintah) yang akan digunakan untuk membiayai program dan kegiatan operasional lembaga sehingga mencapai tujuan. Fundraising tidak hanya dipahami dalam konteks mengumpulkan dana saja sebagaimana makna bahasanya. Hal ini dapat dimengerti karena bentuk kedermawanan dan kepedulian masyarakat tidak harus dalam bentuk dana saja, sehingga sangat dimungkinkan fundraising berupa sumbersumber daya lain selain dana segar. Tujuan dari fundraising zakat adalah menghimpun dana, menghimpun donatur, menghimpun simpatisan dan pendukung, membangun citra lembaga serta memuaskan donatur.

\section{Simpulan}

Persamaan model pengaturan pengelolaan zakat dan pajak yang ada di Indonesia dan Malaysia terdapat beberapa hal salah satunya sistem pengurang pajak setelah membayar zakat yaitu zakat yang telah dibayarkan dapat dikurangkan atau dikreditkan pada SPT PPh Tahunan pada masing-masing negara. Sedangkan perbedaan 


\section{Jurnal Cakrawala Hukum, Volume 12 No. 1 April 2021}

ISSN PRINT 2356-4962 ISSN ONLINE 2598-6538

model pengaturan pengelolaan zakat dan pajak yang ada di Indonesia dan Malaysia adalah BAZNAS \& 332 BAZDA, 19 Lembaga Amil Zakat. Sedangkan di Malaysia terdapat empat belas pusat pungutan zakat, masing-masing satu di negara bagian dan satu di Wilayah Persekutuan Kuala Lumpur.

Permasalahan pengelolaan zakat di Negara Indonesia adalah sebagai berikut: 1) Pengelolaan zakat di masyarakat masih dilakukan secara sederhana dan tradisional. 2) Tingkat kepercayaan yang ada di masyarakat sangat kecil terhadap lembaga pengelola zakat. 3) Adanya dualisme institusi pengelola zakat antara Badan Amil Zakat Nasional (BAZNAS) dan Lembaga Amil Zakat Nasional (LAZNAS). 4) Lemahnya penerapan prinsip pengelolaan organisasi. 5) Rendahnya penguasaan teknologi oleh institusi zakat. 6) Rendahnya pemahaman zakat di kalangan masyarakat. Selanjutnya, upaya yang harus dilakukan untuk memperbaiki mekanisme pengaturan pengelolaan zakat di Negara Indonesia adalah dengan 1) Penyebarluasan pengertian Zakat, 2) Membuat atau merumuskan Fikih Zakat Baru, 3) Pendayagunaan dana yang tersedia, 4) Pengorganisasian dan Fundraising Zakat.

\section{Daftar pustaka}

Afriyandi, Yuli. 2014. Sinergitas Pajak dan Zakat dalam Keuangan Publik Islam (Analisis Historis dan Kondisi Kekinian). Jurnal Rasail, Vol. 1, No. 2.

Ali, Zainuddin. 2010. Metode Penelitian Hukum. Sinar Grafika Jakarta.

Al-Mamun, Abdullah., \& Haque. 2015. Ahasanul. Tax Deduction Through Zakat: an Empirical Investigation on Muslim in Malaysia. ZHARE, Vol. 4, No. 2, Juli-Desember.

Amiruddin, K. 2015, Model-Model Pengelolaan Zakat di Dunia Muslim. Jurnal AHKAM, Vol.3, No. 1, Juli.

Armawy, Armaidi. 2013. Kajian Filosofis-Historis Hubungan Negara dan Agama di Indonesia.
Jurnal Paramita. Universitas Gadjah Mada. Vol. 23 No. 1, Januari.

Ashar. 2013. Pajak dan Zakat: Suatu Kajian Komparatif. Jurnal Fenomena, Vol. V, No. 2.

Asy'ari, Hasyim. 2018. Relasi Negara dan Agama di Indonesia, Jurnal RechtsVinding, Media Pembinaan Hukum Nasional.

Barmawi, Jenny. 1989. Perbandingan hukum Belanda dalam hukum kontinental dan hukum Inggris Amerika. Pusaka Kartin. Yogyakarta.

Darmabrata, Wahyono. 2000. Perbandingan Hukum dan Pendidikan Hukum. Jurnal Hukum dan Pembangunan, No. 4, Oktober.

Hafidhuddin, Didin. 2008. The Power of Zakat Studi Perbandingan Pengelolaan Zakat Asia Tenggara. Cet ke-I. UIN Malang Press. Malang.

Hartono, Sunarjati. 1988. Kapita selekta perbandingan hukum. Citra Aditya Bakti Bandung.

Hidayat, Taufiq. 2013. Menimbang Pemikiran Masdar Farid Mas'udi Tentang Double Taxs (Zakat dan Pajak). Jurnal Economica, Vol. IV, Edisi 2, November.

Lukito, Ratno. 2016. Perbandingan Hukum Perdebatan Teori dan Metode. Gadjah Mada University Press. Yogyakarta.

Magda Ismail A. Mohsin, dkk, Zakah from Salary and EPF: Issues and Challenges. International Journal of Business and Social Science, Vol. 2, No. 1, Januari 2011.

Marzuki, Peter Mahmud. 2005. Penelitian Hukum. Kencana. Jakarta.

Meliala, Djaja S. 1977. Hukum di Amerika Serikat, Suatu Studi Perbandingan. Tarsito. Bandung.

Merangani, Khairul Azhar bin. 2017. Potensi Zakat dalam Pembangunan Umat Islam di Malaysia. Prosiding Seminar Antarbangsa Pembangunan Islam. Tahun 2017.

Noor, Zainulbahar. 2017. Peran Zakat dalam Mendukung Tujuan Pembangunan Berkelanjutan. Laporan Singkat Badan Amil Zakat Nasional Mei.

Percukaian Act 53 Tahun 1967 (Undang-Undang Malaysia). 
Pramuditya. 2014. Diskursus Pajak dan Zakat: Konstekstualisasi dan Aplikasi di Negara Muslim. Jurnal As-Salam, Vol. V, No. 1.

Ridwan, Murtadho. 2014. Zakat Vs Pajak: Studi Perbandingan di Beberapa Negara Muslim. Jurnal Zakat Wakaf, Vol. 1, No. 1, Juni.

Rosdiana, Haula., \& Irianto, Edi Slamet. 2014. Pengantar Ilmun Pajak: Kebijakan dan Implementasi di Indonesia. Raja Grafindo Persada. Jakarta.

Rumaningsih, Endang. 2010. Prospek Integrasi Zakat dengan Pajak. Jurnal ECONOMICA, No. 11, Edisi II, November.

Soekanto, Soerjono, 1989. Perbandingan hukum. Melati. Bandung.

Suprayitno, Eko., dkk. 2013. Zakat Sebagai Pengurang Pajak dan Pengaruhnya Terhadap Penerimaan Pajak di Semenanjung Malaysia. Jurnal Penelitian Sosial Keagamaan, Vol. 7, No. 1, Juni.
Sutedi, Adrian. 2013. Hukum Pajak. Cet. Ke-2. Jakarta: Sinar Grafika.

Undang-Undang Dasar Republik Indonesia Tahun 1945.

Undang-Undang Republik Indonesia No. 10 Tahun 1994 Tentang Pajak Penghasilan.

Undang-Undang Republik Indonesia No. 17 Tahun 2000 Tentang Pajak Penghasilan.

Undang-Undang Republik Indonesia No. 23 Tahun 2011 Tentang Pengelolaan Zakat.

Undang-Undang Republik Indonesia No. 36 Tahun 2008 Tentang Pajak Penghasilan.

Undang-Undang Republik Indonesia No. 38 Tahun 1999 Tentang Pengelolaan Zakat.

Undang-Undang Republik Indonesia No. 7 Tahun 1983 Tentang Pajak Penghasilan.

Undang-Undang Republik Indonesia No. 7 Tahun 1991 Tentang Pajak Penghasilan. 
